\title{
Implementation of a Photovoltaic Panel to Supply Electric Cars Energy Demands
}

\author{
Jardel Eugenio da Silva ${ }^{1^{*}}$, Francielle Rocha Santos ${ }^{2}$, Günther Kaltmaier ${ }^{2}$, Jair \\ Urbanetz Junior 1, 2 \\ ${ }^{1}$ Programa de Pós-Graduação em Sistemas de Energia, Universidade Tecnológica Federal do Paraná, Curitiba, \\ Brasil; ${ }^{2}$ Programa de Pós-Graduação em Engenharia Civil, Universidade Tecnológica Federal do Paraná, \\ Curitiba, Brasil.
}

\begin{abstract}
The gradual shifting of the energy matrix to renewable sources is one of the main global strategies for sustainable development. According to studies, the use of electric energy by automobiles would lead to a reduction in gasoline consumption of $40.7 \%$ in 2031, accompanied by an increase in electricity consumption of $42.1 \%$ in relation to official projections. However, the gradual and constant dissemination and use of electric vehicles, a new paradigm emerges, which is the need to supply the energy demand of this new charge in the electric system The use of solar radiation to generate electricity to meet this new demand presents a sustainable alternative. From these questions, a structure was designed with the installation of a photovoltaic solar panel linked to the use of electric vehicles, analyzing estimated values of energy production and avoided emissions of $\mathrm{CO}_{2}$, compared to the average consumption of several models to cover $21,900 \mathrm{~km}$ per year. The results show that the Renault Twizy was the only model whose consumption was below the energy production of the projected photovoltaic system. In contrast, all models had a positive balance in the estimates of avoided CO2, forming an environmentally sustainable solution.
\end{abstract}

Key words: Photovoltaic energy, electric car.

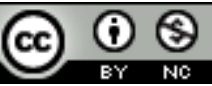

*Author for correspondence: jardel.eugenio@ hotmail.com 


\section{INTRODUCTION}

Electrical energy suply is currently fundamental in human relations and needs. Its uninterrupted availability is a strategic and a critical factor in nations and city systems of our contemporary society. Eletric supplies interruptions may cause economic and safety instability. In Brazil, whose hydroelectric generation corresponds to about $68.1 \%$ of the country's energy matrix ${ }^{1}$ hydrological crises due to droughts caused the blackout crisis between 2001 and 2002, exposing the system's vulnerability.

The use of renewable energy for electricity generation is one of the alternatives for sustainable development. Solar energy, with relative abundancy and availability over the Brazilian territory, is a viable and sustainable alternative for electric generation.

Photovoltaic energy, based on solar energy, begins with the direct and diffuse radiation focusing on a certain surface. The direct radiation corresponds to the rays of sun that come directly at the surface, and the diffuse radiation corresponds to the rays of sun that come indirectly to the surface due to atmospheric dust, clouds or other possible surroundings objects. The photovoltaic modules are composed of cells that convert light into electric energy through the photovoltaic effect of semiconductor materials ${ }^{2}$.

In the automotive industry, electric cars have always been linked to the power source, or lack thereof, either by the autonomy of the accumulators (batteries) or the engines efficiency. Nowadays, the electric vehicles have autonomies beginning at $60 \mathrm{~km}$ (Volteis X4), to $426 \mathrm{~km}$ (Tesla S) ${ }^{3}$, but a new problem arises: the need to supply the energy demand of this new load in the electrical system. According to Baran $^{4}$ the use of electric energy by automobiles would lead to a $40.7 \%$ reduction in gasoline consumption by 2031, accompanied by an increase in electricity consumption of $42.1 \%$ in relation to official projections.

\section{PHOTOVOLTAIC CAR PORCH}

From a commercial perspective, Car Porchs can be an attractive investment for suppliers of energy solutions, who seek to combine design with micro solar energy generation.

This type of structures can be installed independently, reducing or eliminating the need for interventions in existing buildings and structures. Such interventions can lead to higher risks and installations costs, and its construction at ground level allows some advantages in time and construction costs.

The integrated solution, where the modules and panels play a dual role, acting as both roof material and a component of the electric power generation system, reduces costs compared to a building where the panel is simply applied to an existing roof. BIPV systems (Building-integrated photovoltaics) architecture, aesthetics, functionality and energy generation in a holistic solution, where the photovoltaic element assumes a prominent role in design, fulfilling two or more roles in building materials. Thus, replacing roofing materials with photovoltaic components, the original material cost is avoided, makingthis solution economically feasible.

However, it is necessary to solve seals and infiltration between the modules, since most PV products are not manufactured to be used as a cover structure, therefore it is necessary to use specially designed rails and ruffles as a roofing material. 


\section{CAR PORCH DESIGN}

The cover will be installed at the Neoville Campus, of the Federal Technological University of Paraná, in the city of Curitiba. Some criteria and conditions for coverage design were established:

- Easy assembly structure;

- Maximum size of a standard parking space, $2.5 \mathrm{~m}$ x $5.0 \mathrm{~m}$;

- Ideal modules Tilt with ideal azimuth deviation angle (Curitiba 25,51 S; 49,27 W);

- Use of a maximum of four PV modules;

According to the criteria adopted for the elaboration of the project, the gridconnected photovoltaic power system will have the following characteristics and specifications:

- Photovoltaic array composed by four modules of $315 \mathrm{Wp}$ connected in series, measuring about $1.0 \mathrm{~m} \times 2.0 \mathrm{~m}$;

- EcoSolys Ecos 1000 model inverter;

- Modules tilt $25^{\circ}$ angle and $0^{\circ}$ azimuthal deviation (North orientation).

- Structure plan measuring $2,5 \mathrm{~m} \times 4,0 \mathrm{~m}\left(10,0 \mathrm{~m}^{2}\right)$;

Other devices were projected like electric plugs and electrical plumbing, attached to a fixed totem. The design of the structure is illustrated in Figure 1.
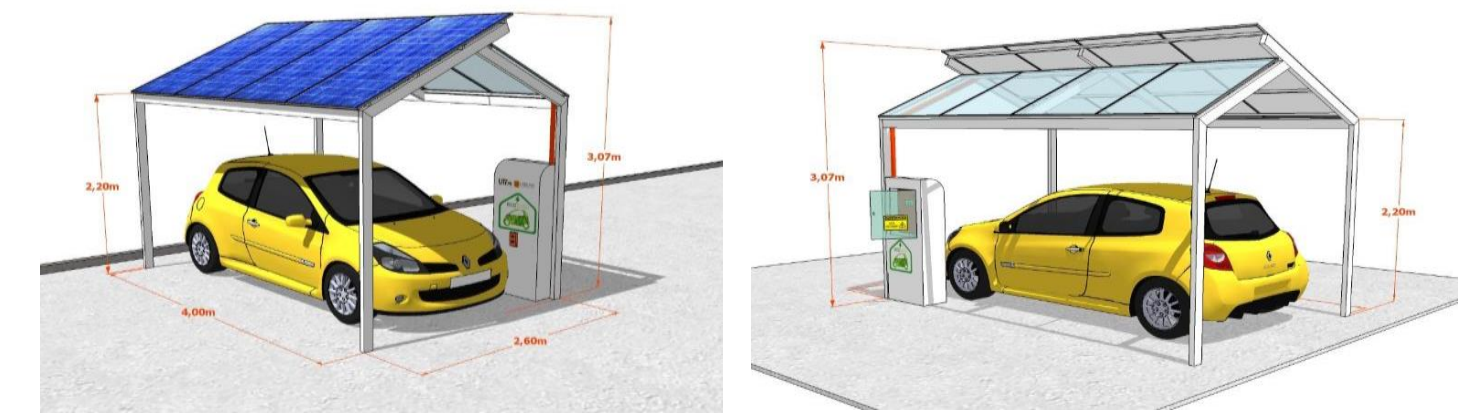

Figure 1- Car porch Design.

Source: Tha autors 2017.

\section{ELECTRIC VEHICLES}

Electric cars are a more environmentally friendly option. However, in Brazil there are no government incentives, so the purchase values are still high. Silva, Tonin, Urbanetz ${ }^{5}$ explains that when the electric motor is turned on, it absorbs $90 \%$ of the amount of electrical energy and turns it into torque, that is, mechanical power. The electric engine transforms the electrical power into mechanical power, with a reduced percentage of losses.

The world scenario highlights that electric cars will trend in the next few years, but Brazil is moving slowly into this future scenario. The automotive industry market makes it clear that the trend for the coming years is electric vehicles. Countries such as Norway and Holland were the largest buyers of electric vehicles in the first quarter of $2015 .{ }^{6}$

To calculate the autonomy and average consumption of electric vehicles, the manufacturers data of these vehicles are shown in Table 1. 
Table 1- electric vehicles autonomy

\begin{tabular}{ccrr}
\hline Model & $\begin{array}{c}\text { Energy Consumption } \\
\text { in 100 km (kWh) }\end{array}$ & $\begin{array}{c}\text { Autonomy } \\
\mathbf{k m})\end{array}$ & $\begin{array}{c}\text { Battery Energy } \\
(\mathbf{k W h})\end{array}$ \\
\hline Renault Twizy 45 & 5.10 & 120 & 6.10 \\
\hline Mega City & 9.00 & 100 & 9.00 \\
\hline Mia Electric & 10.00 & 80 & 8.00 \\
\hline Lumeneo Neoma & 10.10 & 140 & 14.20 \\
\hline Renault Zoé & 10.50 & 210 & 22.00 \\
\hline Citroën C-Zéro & 10.70 & 150 & 16.00 \\
\hline Little 4 & 11.00 & 100 & 11.00 \\
\hline Renault Fluence Z.E & 11.90 & 185 & 22.00 \\
\hline Bolloré Bluecar & 12.00 & 250 & 30.00 \\
\hline Smart Fortwo E.D. & 12.10 & 145 & 17.60 \\
\hline Renault Kangoo Z.E. & 12.90 & 170 & 20.00 \\
\hline Nissan Leaf & 13.70 & 175 & 24.00 \\
\hline Ford Focus EV & 14.30 & 160 & 23.00 \\
\hline FAM F-City & 14.40 & 100 & 14.40 \\
\hline Tesla Roadster & 15.10 & 350 & 53.00 \\
\hline Volteis X4 & 19.10 & 60 & 14.50 \\
\hline Tesla S & 19.90 & 426 & 85.00 \\
\hline Source: Adapted ${ }^{3}$ & & &
\end{tabular}

\section{METHOD}

The photovoltaic energy generation estimate was performed initially using the number of modules to calculate their power. The power of each module is multiplied by the number of modules to achieve the system installed power (Pfv). ${ }^{7}$

$$
P_{F v}=P_{m o ́ d} \times N_{m o ́ d}
$$

where:

$\mathrm{P}_{\mathrm{Fv}}$ is ther installed power;

$\mathrm{P}_{\text {mód }}$ Is the nominal power of each PV module

$\mathrm{N}_{\text {mód }}$ is the total number of modules.

The daily energy can be achieved through equation 2 based on the work of Mariano, Santos, Brito, Urbanetz, Casagrande ${ }^{8}$. The value of Htot considered was $5.55 \mathrm{kWh} / \mathrm{m}^{2} /$ day. This value was applied in the calculation of the daily electric energy generation (equation 2) resulting in $5.24 \mathrm{kWh} /$ day, which multiplied by 365 days results in an average annual energy of $1,912.60 \mathrm{kWh} /$ year.

$$
E_{f v}=\underline{P}_{F V} \times H_{t o t} \times P R \times 365
$$

Where:

Efv is annual electricity to be generated $(\mathrm{kWh} /$ year); Htot is the solar radiation available $\left(\mathrm{kWh} / \mathrm{m}^{2} \mathrm{x}\right.$ day); PR is the Performance Ratio (between $70 \%$ to $80 \%$ ); $\mathrm{G}$ is the average irradiance at the Earth's surface $\left(1,000 \mathrm{~W} / \mathrm{m}^{2}\right)$. 
According to Silva, Tonin, Urbanetz $\mathrm{z}^{5}$ after a number of surveys the manufacturers have concluded that $60 \mathrm{~km}$ per day is an average of the distance traveled by drivers to carry out their daily activities, that average varies from $40 \mathrm{~km}$ (UK) to an average of $80 \mathrm{~km}$ (Poland)". Thus, it was adopted as base $60 \mathrm{~km} / \mathrm{day}$, which multiplied by the amount of annual days, results in $21,900 \mathrm{~km} / \mathrm{year}$. This value was used to estimate the energy needed for each model to travel one year according to table 2, calculated by equation 2 :

$$
\text { Eyear }=(\mathrm{E} 1 / 100) \times 21,900.00 \mathrm{~km} / \mathrm{year}
$$

Where:

Eyear is the energy required to run $21,900 \mathrm{~km} /$ year

E1 is the energy to run $100 \mathrm{~km}(\mathrm{kWh})$

These values were used to estimate the amount of $\mathrm{CO}_{2}$ avoided by the SFVCR/vehicle set, according to each model.

\section{RESULTS AND DISCUSSIONS}

The electric car will be used during the daytime period, exactly when the panel will be generating power, and charged at night, using the distributor's energy to charge it. As the generation and use of the vehicle occurs concurrently, the energy produced must be sent to the distribution system, so the energy generated by the panel during the day will be sent to the public grid using the electric compensation system.

With the result of equations 2 and 3, it was possible to verify the energy balance, that is, the difference between the demanded energy E1 and the generated energy Efv. This result represents the energy that will have to be served by the network, or in case of a positive energy balance, credits are obtained from the distribution company. This value was calculated by equation 4 .

$$
\mathrm{Er}=\mathrm{Efv}-\text { Eyear }
$$

Where:

Er is the energy that will be served by the grid $(\mathrm{kWh} /$ year).

This result was used in equation 5, which represents the percentage of energy supplied by the SFVCR in relation to the energy demanded $(\mathrm{kWh})$ for each model to cover $21,900 \mathrm{~km}$ per year.

Where:

$$
\mathrm{Eb}=\mathrm{Efv} / \text { Eyear }
$$

$\mathrm{Eb}$ is the percentage of energy served by SFVCR in relation to the energy demanded $(\mathrm{kWh})$ for each model to cover $21,900 \mathrm{~km}$ per year.

Then it was calculated the $\mathrm{CO}_{2}$ avoided, having 3 factors. The first is the amount of $\mathrm{CO}_{2}$ avoided for electricity generation, that is, each $\mathrm{kWh}$ generated by the panel with a renewable source avoids emission corresponding to the emissions of the Brazilian energy matrix. Each $\mathrm{kWh}$ generated with a renewable source would avoid $0,1013 \mathrm{~kg}$ of $\mathrm{CO}_{2}$ in the atmosphere. The second factor corresponds to the $\mathrm{CO}_{2}$ avoided per km driven by electric energy, that is, the amount of $\mathrm{CO}_{2}$ avoided in comparison to the amount of $\mathrm{CO}_{2}$ emitted by the use of a combustion drive vehicle. On average, a ride vehicle with $1.0 \mathrm{cc}$ to $2.0 \mathrm{cc}$ engine emits on average $0.06329 \mathrm{~kg}$ of $\mathrm{CO}_{2}$ for each kilometer driven, which multiplied by $21,900 \mathrm{~km} /$ year 
results in about $1,386.05 \mathrm{~kg}$ of $\mathrm{CO}_{2} /$ year. And the third factor refers to the energy balance, that is, the amount of energy that needed to be complemented by the network energy multiplied by the emissions compatible with the Brazilian electricity generation matrix to produce each $\mathrm{kWh} .{ }^{1}{ }^{\mathrm{T}} \mathrm{Tis} \mathrm{CO}_{2}$ balance, released or avoided, was calculated by equation 6 .

$$
\mathrm{CO}_{2}=(\operatorname{Efv} \times 0.1013)+\mathrm{CO}_{2} \mathrm{R}+(-\mathrm{Er} \times 0.1013)
$$

Where:

$\mathrm{CO}_{2}$ is the amount of $\mathrm{CO}_{2}$ avoided $(\mathrm{kg})$;

$\mathrm{CO}_{2} \mathrm{R}$ is the amount of $\mathrm{CO}_{2}$ avoided by running with an electric source $(1,386.05$ $\mathrm{kg} /$ year);

$\mathrm{E}_{\mathrm{r}}$ is the energy that will be served by the grid ( $\left.\mathrm{kWh} / \mathrm{year}\right)$.

Table 2- Comparison between estimated energy production and consumption of several electric cars

\begin{tabular}{crrrrr}
\hline Model & E1(kWh) & $\begin{array}{c}\text { Eyear } \\
(\mathbf{k W h} / \mathbf{y e a r})\end{array}$ & Er(kWh) & Eb(\%) & CO2 avoided \\
\hline Renault Twizy 45 & 5.10 & $1,116.90$ & -795.70 & 171.24 & $1,660.40$ \\
\hline Mega City & 9.00 & $1,971.00$ & 58.40 & 97.04 & $1,573.88$ \\
\hline Mia Electric & 10.00 & $2,190.00$ & 277.40 & 87.33 & $1,551.70$ \\
\hline Lumeneo Neoma & 10.10 & $2,211.90$ & 299.30 & 86.47 & $1,549.48$ \\
\hline Renault Zoé & 10.50 & $2,299.50$ & 386.90 & 83.17 & $1,540.60$ \\
\hline Citroën C-Zéro & 10.70 & $2,343.30$ & 430.70 & 81.62 & $1,536.17$ \\
\hline Little 4 & 11.00 & $2,409.00$ & 496.40 & 79.39 & $1,529.51$ \\
\hline Renault Fluence Z.E & 11.90 & $2,606.10$ & 693.50 & 73.39 & $1,509.54$ \\
\hline Bolloré Blueca & 12.00 & $2,628.00$ & 715.40 & 72.78 & $1,507.33$ \\
\hline Smart Fortwo E.D. & 12.10 & $2,649.90$ & 737.30 & 72.18 & $1,505.11$ \\
\hline Renault Kangoo & 12.90 & $2,825.10$ & 912.50 & 67.70 & $1,487.36$ \\
\hline Z.E. & 13.70 & $3,000.30$ & 1.087 .70 & 63.75 & $1,469.61$ \\
\hline Nissan Leaf & 14.30 & $3,131.70$ & 1.219 .10 & 61.07 & $1,456.30$ \\
\hline Ford Focus EV & 14.40 & $3,153.60$ & 1.241 .00 & 60.65 & $1,454.08$ \\
\hline FAM F-City & 15.10 & $3,306.90$ & 1.394 .30 & 57.84 & $1,438.55$ \\
\hline Tesla Roadster & 19.10 & $4,182.90$ & 2.270 .30 & 45.72 & $1,349.81$ \\
\hline Volteis X4 & 19.90 & $4,358.10$ & 2.445 .50 & 43.89 & $1,332.07$ \\
\hline Tesla S & & & & & \\
\hline Source: Authors, 2017. & & & & \\
\hline
\end{tabular}

Source: Authors, 2017.

The results obtained in Table 2 demonstrates that the Renault Twizzy has the lowest consumption of electricity, having at the end of the year a surplus of energy, according to the average of 21,900 km/year traveled. According to the Agencia Nacional de Energia Eletrica (ANEEL) - National Electric Energy Agency, this surplus would generate energy credits in energy distribution companies. However, the solar panel would generate only $44 \%$ of energy for the Tesla $\mathrm{S}$ vehicle, being the use of energy from the distributor necessary, to run $21,900 \mathrm{~km} /$ year.

However, the use of photovoltaic energy reduces the impacts caused by the greenhouse effect, resulting from the burning of fossil fuels. According to Santos ${ }^{9}$ the amount of carbon dioxide that can be avoided, the energy generation of the photovoltaic has to be linked to it, which should be multiplied by 0.064 ; resulting in the value in $\mathrm{kg}$ of $\mathrm{CO}_{2}$.

It can be noticed that even with positive energy balance, all models would have a positive $\mathrm{CO}_{2}$ balance, that is, they would generate carbon credits. 


\section{CONCLUSIONS}

With the increasing accessibility and demand for fossil fuel-powered motor vehicles, and the characteristic pollution factors of these types of engines, electric vehicles appear as a less polluting and environmentally responsible alternative. The increase in the demand for electric energy, as an inherent consequence and collateral to this process, demands the search for renewable sources of generation, since the electric generation from fossil sources would imply in the increase of the emissions, which could have a reverse environmental effect. In this articled a SFVCR was designed with $1.26 \mathrm{kWp}$, which is intended to be implemented to generate electric energy concomitantly to the use of electric vehicles, seeking to combine generation, mobility and electric demand in a sustainable set. According to the characteristics of each model, there is a higher or lower balance of energy used in the power grid. The results demonstrate a positive $\mathrm{CO}_{2}$ balance for all models due to avoided emissions, either by photovoltaic electric generation or by the utilization of electric vehicles, which implies a coherent and responsible environmental solution, in line with the overall path in the sustainable development.

\section{REFERENCES}

1- Personal Co2 Zero. Ranking de veículos em emissões de Co2 por km rodado, 2012. [Internet]. [acesso em 2017 ago 14]. Available in:

https://www.personalco2zero.com/estudo_emissoes_CO2/EstudoEmissoesporKM_revisado14 nov.pdf

2- Patel MR. Wind and solar power systems: Design, analysis, and operation. 2 eds.

Florida, Estados Unidos: CRC Press, 2006.

3- Meunier N. La vérité sur la consommation des voitures électriques: Magazine

Challenges, 2012. [Internet]. [acesso 2016 abr 03]. Available in:

http://automobile.challenges.fr/dossiers/20120807.LQA3178/la-verite-sur-la-consommation-

des-voitures-electriques.html

4- Baran R. A introdução de veículos elétricos no Brasil: Avaliação do Impacto no

consumo de gasolina e eletricidade, 2012. Tese de Doutorado. Universidade Federal do

Rio de Janeiro. [Internet]. [acesso 2017 jul 07]. Available in:

http://www.ppe.ufrj.br/ppe/production/tesis/baran.pdf

5- Silva JE, Tonin F, Urbanetz JJ. Veículos elétricos e a geração distribuída

partir de sistemas fotovoltaicos: Conferência internacional de energias inteligentes.

Curitiba, 2016.

6- Mccarthy N. Oito países com maior mercado de carros elétricos no $1^{\text {o }}$ trimestre de 2015. Revista Forbe 2015.

7- Urbanetz JJ. Manual para dimensionamento de sistemas fotovoltaicos. Curitiba, 2015: 11 .

8- Mariano JD, Santos FR, Brito GW, Urbanetz JJ, Casagrande JEF. Hydro thermal and photovoltaic power plants: A comparison between electric power generation, environmental impacts and $\mathrm{CO} 2$ emissions in the Brazilian scenario. Energy and environmental, 2016. Volume 7, Issue 4: 347-356.

9- Santos IP. Desenvolvimento de ferramenta de apoio à decisão em projetos de integração solar fotovoltaica à arquitetura. 2013. Tese de Doutorado em Engenharia Civil. Universidade Federal de Santa Catarina. [acesso em 14 de agosto de 2017]. Available in: http://fotovoltaica.ufsc.br/Teses/Tese_IsisPortolanDosSantos.pdf 